Journal of the Bangladesh Association of Young Researchers (JBAYR), Volume 1 Number 1, January 2011, Page 15-30

ISSN 1991-0746 (Print), ISSN 2220-119X (Online), DOI: 10.3329/jbayr.v1i1.6838

\section{IMPACT OF LIVELIHOOD PRACTICES ON THE CHAR DWELLERS ECONOMIC CONDITION IN RIVERINE CHARS: CASE STUDIES IN BANGLADESH}

\section{Mohammad Arifur Rahman and Md. Munsur Rahman}

Institute of Water and Flood Management, Bangladesh University of Engineering and Technology, Dhaka-1000, Bangladesh.

E-mail: arif_es36@yahoo.co.uk,mmrahman@iwfm.buet.ac.bd

\section{ABSTRACT}

The present study tries to identify the livelihood practices of the char dwellers. It also focus to assess their economic condition in relation to livelihood practices. The research has been conducted through interdisciplinary approach. Different socio technical tools are used to analyze the problem. Local people's participation in the research process has ensured by using Participatory Rural Appraisal (PRA) tools. The total population is 969 among them 478 are male and 481 are female and about 215 households live in the Char Konabari of which about 60 percent people are engaged in handloom activities as labor as their main source of livelihood. Agriculture is the second highest and about 20 percent people are engaged in such practice; about four percent people are engaged in small business (broker, small retailer) and rests others are engaged in day labor activities and others like van driver etc. The total numbers of employed people of Char Konabari is 267. Out of them only 54 people engaged with farming activities and others are involved with non-farming activities. One-fourth of the total employed person earned the two-third of the total yearly income of the village and remaining four-fifth employed person earned only one-third of the total yearly income. On the other hand about 586 households live in Dakshin Boro-char of which about $60 \%$ and $30 \%$ people are agricultural farmer and fishermen. On-farm activities are dominant in Dakshin Borochar. Most of the farmers have their own land as well as they also cultivate khas (public) land. The rest of the people are engaged in day labor activities, petty business and others (boatsmen). Cultivated land, Domestic animal, grazing land and wet land are the major natural resources of Dakshin Boro-char. The total numbers of employed people of Dakshin Boro-char are 598 and most of them are engaged in agricultural and fisheries activities.The daily per capita income of the Char Konabari and Dakshin Boro-char is about US\$0.54 and US\$0.87 respectively. Although women are involved in livestock rearing, their contribution did not recognize socially and economically.

KEYWORDS: Livelihood, Resource, Char dwellers, Char Stability, Inter disciplinary.

\section{INTRODUCTION}

Bangladesh was, and continues to be, formed by sedimentation and accretion of three rivers the Jamuna, the Padma and the Meghna as they flow from the Himalayas to the Bay of Bengal. Extensive char areas have been created along the bed or basin of these big rivers. Char lands are the sandbars that emerge as islands within the river channel or as attached land to the riverbanks. EGIS, 2000 found that on an average $5 \%$ of Bangladeshi population as well as 6.5 million people live on the Chars covering almost $5 \%$ of the total land area of the country and miserably it is narrowed as 7,200 square kilometers. The riverine sand and silt landmasses known as char in Bengali are home to over 5 million people in Bangladesh (Kelly and Chowdhury, 2002).

The present study areas are located at two different morphological conditions. The bed material size of Jamuna River and Padma River is 0.20 $\mathrm{mm} ; 0.12 \mathrm{~mm}$ respectively. The Ganges, Padma and lower Meghna Rivers are categorized as wandering rivers, showing a mixed pattern of meandering and braided stretches. The chars in these rivers seem to be more stable than in the Jamuna River. It is to be noted that the active corridor of the Ganges River is bounded by erosion-resistant materials. This might have contributed to the stability of the chars in this river. Besides this, the stability of chars in wandering rivers could be explained by the fact that in such rivers attached chars develop out of island chars, which results in a continuity in the process of char formation. This is absent in a braided river like Jamuna, where the attached and island char are 
formed more randomly and independently (Sarker et. el, 2003). The dynamics of river is also different between Padma and Jamuna. The floodplains along the right bank of the Jamuna River are older than those along the left bank. Though a long term westward migration trend is present, the bank erosion was higher along the left (east) bank during the widening phase of the rivers. Similarly, the floodplains along the left bank of the Padma and lower Meghna rivers are older than those along the right bank, and the length-averaged bank erosion rate was found to be much higher along the left bank (ISPAN, 1995). The present study tries to identify the livelihood practices of the char dwellers.

\section{METHODOLOGY}

The research has been conducted through interdisciplinary approach. Different socio technical tools are used to analyze the problem. Local people's participation in the research process has ensured by using Participatory Rural Appraisal (PRA) tools like Discussion tools (Focus Group Discussion - FGD, Semi Structure Interview), Mapping Tools (Resource mapping, Transect walk), Diagramming tools (Seasonal Calendar). This interdisciplinary approach enables the researcher to gain in-depth understanding of the issues raised through the PRA practices. PRA enables rural people to share, enhance and analyze their knowledge of life and conditions, to plan and to act (Chambers, 2002). For the study several FGD is conducted with agricultural farmer, fishermen and handloam worker of different age group (Group 1: Age 18-30 years, Group 2: Age 31-45 years, Group 3: Age 46-60 years).

In addition to this, a formal semi-structure questionnaire is designed in an easy way that is relevant to the resource and livelihoods practices of the char dwellers for questionnaire survey. Simple random technique has been applied as sampling procedure. Simple Random Sampling from a finite population refers to that method of sample selection, which gives each possible sample combination an equal probability of being picked up and each item in the entire population to have an equal chance of being included in the sample (Kothari, 1996). The study also considers the special gender needs in the respective area. Soil texture and soil organic content are prominent factors for soil fertility. In the present research sieve analysis is used for soil classification.
The per capita income noted that the total income divided the total population of the specific region. Hence, the per capita income of a char is calculated the following equation:

Per capita Income=Total Income from different occupation / Total Population of the specific char.

\section{The Study Area}

The study area is selected on the basis of stability of the char (less stable char, stable char) as well as location of the char (attached char and within the river char). Some additional selection criteria also considered; such as local livelihood pattern and alternative options, household consistency, agricultural concentration, communication and community responsiveness.

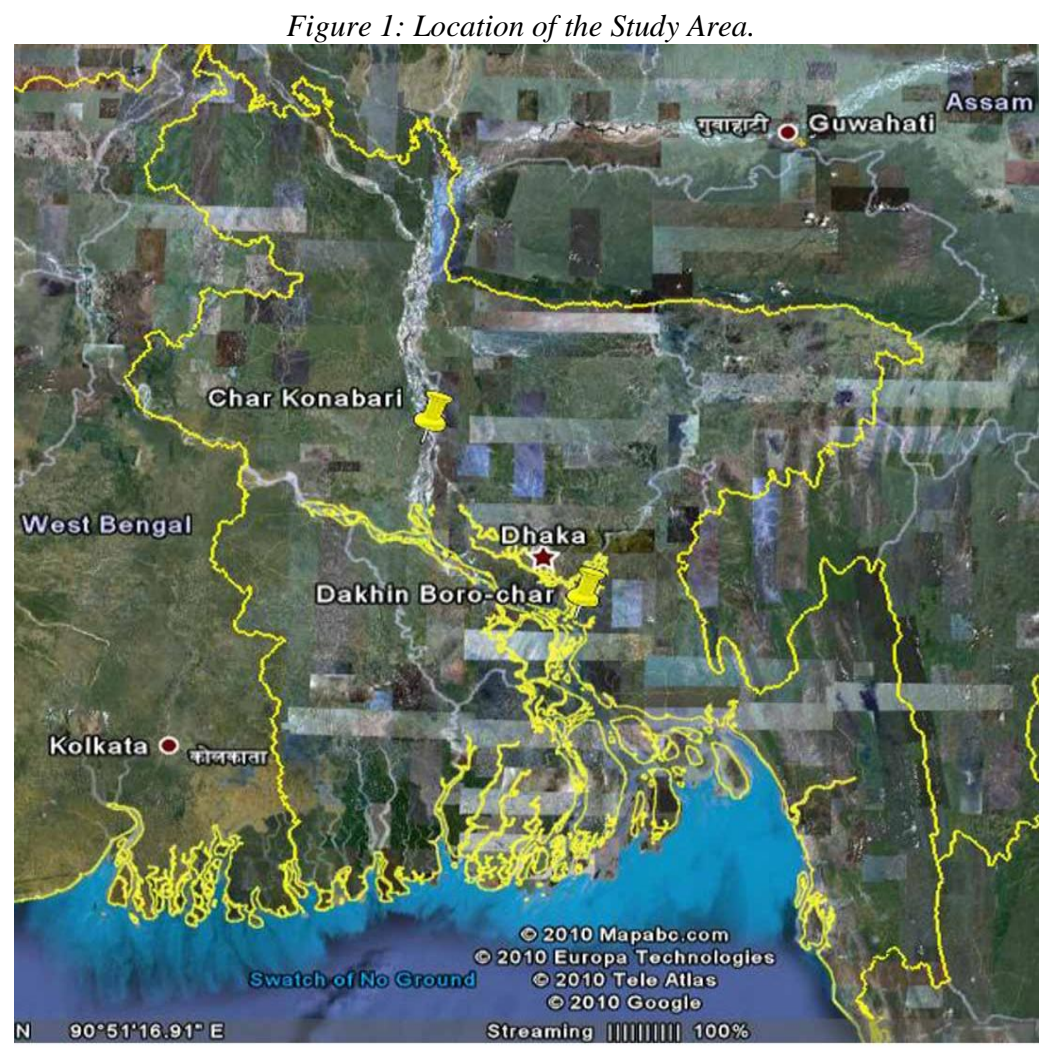


The char Konabari of Rajapur union under Belkuchi Upazila, Sirajganj district and Dakshin Boro-char of Eklashpur union under Uttar Matlab, Chandpur district is selected for the present study. The char Konabari is a less stable char and emerged during 1998 flood. However, the Dakshin Boro-char is a stable char and emerged in the year 1970. The char Konabari is situated on the eastern side of the branch channel of Jamuna River and the Dakshin Boro-char is placed on the confluence of Padma-Meghna are shown in Figure 1.

\section{RESULTS AND DISCUSSIONS}

\section{Char Formation Process}

The vegetated landmasses within the riverbanks of Bangladesh, which are commonly known as chars, have long been inhabited by a large number of people. Newly formed char consists of sand of approximately the same coarseness as the bed material of the river reach. First two or three years erosion or accretion of the char is the natural phenomena. Char dwellers cultivated Ground nuts and Dhaincha/Catkin if fine materials deposited on the bed of the char. This process would continue more or less five years until the land enriched with minerals like nitrogen and silt/clay. Dhaincha (sesbania aculeata) and Ground nuts are leguminous plant those can fix nitrogen directly from air into the soil by their special roots. In addition due to Catkin (Saccharum spontaneum) grown every year a layer of silt and clay is deposited over the sand layer when the char elevation reaches close to average flood level. After ten to twelve years, the char land make suitability for cultivation of rice as well as people have been migrated from adjacent char and inhabit in the fertile land due to resource availability. They make their house in the barren land in the char area. The coordination among people and fertile land with the influence of river formed a complete char land. The entire process would be completed within twelve to fifteen years. At the final stage the newly formed char turned into a stable char.

\section{Soil Classification and Organic Content}

The present study revealed that about $71 \%$ and $50 \%$ soil particle is less then $0.075 \mathrm{~mm}$ in the agricultural field of Char Konabari and Dakshin Borochar respectively. AASHTO Classification Chart shows that both of the soil is silty clay. The organic content is $1.68 \%$ and $2.18 \%$ of Char Konabari and Dakshin Boro-char respectively, shown in Table 1.

The Old Brahmaputra (present Jamuna) floodplain soil has low fertility (1.0\% to $1.7 \%$ organic matter) and the Ganges river floodplain soil has low to medium fertility ( $1 \%$ to $3.4 \%$ organic matter). A good soil should have $2.5 \%$ organic matter (BARC, 2005).

Table 1: Soil Classification and Organic Content

\begin{tabular}{|c|c|c|c|c|}
\hline \multirow{2}{*}{$\begin{array}{c}\text { Particle } \\
\text { diameter } \\
\text { (mm) }\end{array}$} & Char Konabari & $\begin{array}{c}|c| \\
\text { Dakshin Boro- } \\
\text { char }\end{array}$ & $\begin{array}{c}\text { Organic Content (\%) } \\
\text { Konabari }\end{array}$ & $\begin{array}{c}\text { Dakshin } \\
\text { Boro- } \\
\text { char }\end{array}$ \\
\cline { 2 - 3 } & 100 & 100 & & \\
\hline 4.75 & 99 & 100 & \multirow{2}{*}{1.68} & \multirow{2}{*}{2.18} \\
\hline 2.36 & 89 & 98 & \\
\hline 1.18 & 80 & 94 & \\
\hline 0.6 & 68 & 91 & \\
\hline 0.3 & 58 & 83 & & \\
\hline 0.15 & 50 & 71 & & \\
\hline 0.075 & & \multicolumn{2}{|c|}{90} & \\
\hline
\end{tabular}

\section{Livelihood Practices}

Household survey revealed that the total population of Char Konabari is about 969 in numbers in which 478 are male and 481 are female; however the total population of Dakshin Boro-char is about 2745; among them 1355 are male and 1390 are female. About 215 households live in the Char Konabari of which about $60 \%$ people are engaged in handloom activities as labor, which are their main source of livelihood. Agriculture is the second highest and about $20 \%$ people are engaged in such practice; among the agricultural farmers, $50 \%$ have their own land and rest of them are landless. About $4 \%$ people are engaged in business (petty business) and rest of the people are engaged in day labor activities, van driver and others (boats men) are shown in Figure 2. On the other hand about 586 
households live in Dakshin Boro-char of which about $60 \%$ and $30 \%$ people are agricultural farmer and fishermen. On-farm activities are dominant in Dakshin Boro-char. Most of the farmers have their own land as well as they also cultivate khas (public) land. The rest of the people are engaged in day labor activities, petty business and others (boats men) are also shown in Figure 2.

Figure 2: Livelihood practices of Dakshin Boro-char and Char Konabari

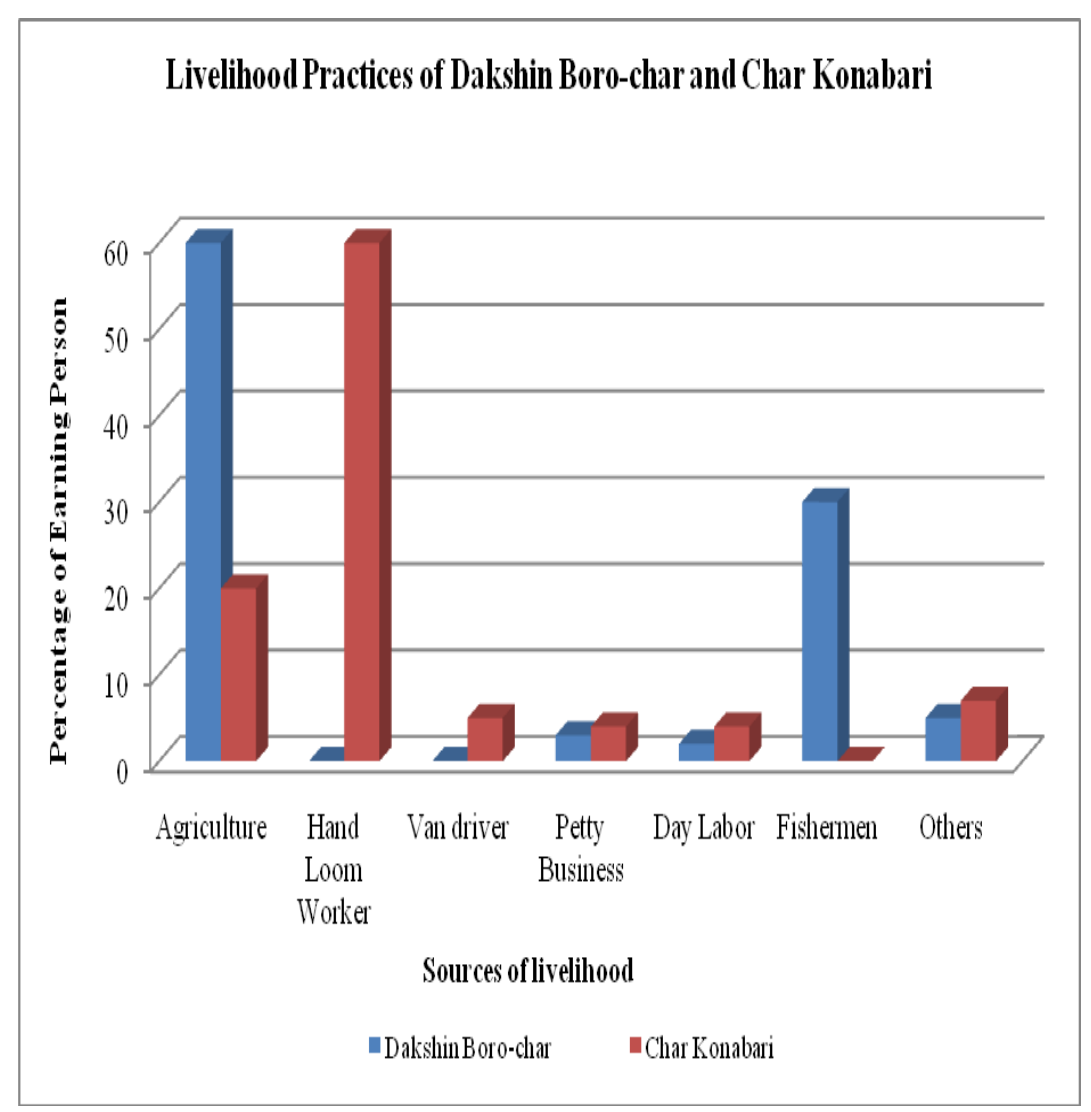

\section{Crop Production}

Different types of crops are cultivated in different seasons of the year in Char Konabari and Dakshin Boro-char. The crop calendar of Char Konabari and Dakshin Boro-char are shown in Table 2. Apparently three different cropping pattern in a year shows in Char Konabari. These are: 1) Mustard Rice (Boro) - Vacant 2) Jute/Dhaincha-Pulses -Vacant and 3) Wheat-Rice (Aman)-Vacant. But in Dakshin Boro-char have two cropping pattern such as Rice (Boro) - Vacant and Jute/Dhaincha - Mustard/Potato/Pepper.

The present study shows that during winter season, various Rabi crops such as oil seeds (mustard), pulses (lentil) and wheat are grown in the field of Char Konabari as well as mustard, potato, pepper are in the field of Dakshin Boro-char. Jute and Dhaincha are grown during rainy season in both of the char. The char dwellers of Konabari cultivate two types of rice but only Boro rice is cultivated in Dakshin Boro-char. The Boro season starts from mid January and continue to mid May and Amon season starts from mid July continue to mid November. Dhaincha is cultivated from mid April to mid October and cropping period of jute is mid April to mid August. Mustard and Pepper are cultivated during mid November to mid March and potato is also cultivated during December to mid March. Wheat and Pulses are cultivated during December to mid March.

Table 3 shows the total crop production and market price of different crops of Char Konabari and Dakshin Boro-char. The total earning from crop production is about 30 lac and 203 lac per annum of Char Konabari and Dakshin Boro-char respectively. 
Table 2: Crop Calendar

\begin{tabular}{|c|c|c|c|c|c|c|c|c|c|c|c|c|}
\hline \multirow{2}{*}{ Name ofCrops } & \multicolumn{12}{|c|}{ Name of Month } \\
\hline & Jan & Fel) & Mar & Appr. & May & June. & July & Aosst, & Sept, & Oct. & Nov, & Dec. \\
\hline \multicolumn{13}{|c|}{ Char Konabari } \\
\hline \multicolumn{13}{|l|}{ Rice } \\
\hline \multicolumn{13}{|l|}{ Boro (BR-29) } \\
\hline \multicolumn{13}{|l|}{ Aman-Kartilk } \\
\hline \multicolumn{13}{|l|}{ Ohaincha } \\
\hline \multicolumn{13}{|l|}{ Jute } \\
\hline \multicolumn{13}{|l|}{ Mustard } \\
\hline \multicolumn{13}{|l|}{ Wheat } \\
\hline Pulses (Lentil) & & & & & & & & & & & & \\
\hline \multicolumn{13}{|c|}{ Dakshin Boro-char } \\
\hline \multicolumn{13}{|l|}{ Rice } \\
\hline \multicolumn{13}{|c|}{ Boro BR-28, } \\
\hline \multicolumn{13}{|c|}{ 29) } \\
\hline \multicolumn{13}{|c|}{ Jute } \\
\hline \multicolumn{13}{|l|}{ Ohaincha } \\
\hline \multicolumn{13}{|l|}{ Mustard } \\
\hline \multicolumn{13}{|l|}{ Potato } \\
\hline Pepper & & & & & & & & & & & & \\
\hline
\end{tabular}

Mohammad Arifur Rahman and Md. Munsur Rahman

Table 3: Total Crop Production and Market Price of Different Crops

\begin{tabular}{|c|c|c|c|c|c|}
\hline $\begin{array}{c}\text { Name of } \\
\text { Crops }\end{array}$ & Variety & $\begin{array}{l}\text { Amount of } \\
\text { cultivated } \\
\text { land (ha) }\end{array}$ & $\begin{array}{c}\text { Total } \\
\text { Production } \\
\text { (MT) }\end{array}$ & $\begin{array}{c}\text { Price } \\
\text { (Tk./MT) }\end{array}$ & $\begin{array}{c}\text { Total Price } \\
\text { (Tk.) }\end{array}$ \\
\hline \multicolumn{6}{|c|}{ Char Konabari } \\
\hline \multirow[b]{2}{*}{ Rice } & $\begin{array}{c}\text { Boro (BR- } \\
29)\end{array}$ & 5 & 40 & 17000 & 680000 \\
\hline & $\begin{array}{l}\text { Aman- } \\
\text { kartic, } \\
\text { siraj }\end{array}$ & 5 & 10 & 17000 & 170000 \\
\hline Dhaincha & & 10 & 35000 unit & 10Tk/unit & 350000 \\
\hline Mustard & & 5 & 3.5 & 32000 & 112000 \\
\hline Wheat & & 5 & 10 & 17000 & 170000 \\
\hline $\begin{array}{l}\text { Pulses } \\
\text { (Kalai, } \\
\text { Lentil) }\end{array}$ & & 20 & 14 & 60000 & 840000 \\
\hline \multirow{2}{*}{ Jute } & & \multirow{2}{*}{10} & 8 & 35000 & 280000 \\
\hline & & & 35000 unit & 10Tk/unit & 350000 \\
\hline \multicolumn{5}{|c|}{ Total earning } & 2952000 \\
\hline \multicolumn{6}{|c|}{ Dakshin Boro-char } \\
\hline Rice & $\begin{array}{l}\text { Boro (BR } \\
28,29)\end{array}$ & 65 & 455 & 14500 & 6597500 \\
\hline Mustard & & 6 & 6 & 37000 & 222000 \\
\hline Potato & & 39 & 780 & 7000 & 5460000 \\
\hline Pepper & & 20 & 24 & 120000 & 2880000 \\
\hline \multirow{2}{*}{ Jute } & & \multirow{2}{*}{39} & 78 & 37500 & 2925000 \\
\hline & & & 136500 unit & 10Tk/unit & 1365000 \\
\hline Dhaincha & & 26 & 91000 unit & 10Tk/unit & 910000 \\
\hline \multicolumn{5}{|c|}{ Total earning } & 20359500 \\
\hline
\end{tabular}

\section{Livestock and Poultry}

Livestock and poultry are other important livelihood activities in Char area. Cow and goat are the mentionable cattle. In each year the char Konabari produces almost 188 cows, 238 goats and 1000 hens. However the Dakshin Boro-char produces almost 2344 cows and 4100 hens. Goats are rare in the remote Dakshin Boro-char due to lack of veterinary surgeon. The local people noted that goats faced many diseases as compared to cattle. The economic activity mobilizes through these natural resources and the 
farmers of the area earn huge money by selling their domestic animals as its prices are so high on an average the price of a cow, a goat and a hen are Tk. 10,000; Tk. 2,000 and Tk. 200 respectively. The dwellers of Char Konabari and Dakshin Boro-char also earn a handsome amount by producing milk and eggs as well as about Tk. 36 lac and Tk. 130 lac per annum respectively.

\section{Non Agricultural Works}

The non agricultural works like handloom worker, van driver and petty business are common livelihood practices in Char Konabari. During the rainy season the handloom workers do not have any work. Generally, non agricultural workers are getting about Tk. 2,500 per month in the adjacent area of Char Konabari. On the other hand in Dakshin Boro-char the fishermen, van driver and petty business are common non agricultural occupations. The fishermen and others non agricultural workers are getting Tk. 6,000 and Tk. 4,500 per month respectively.

\section{Livelihood Resources}

The land area of Char Konabari is about 53 hectare, out of that 30 hectare land are used for agricultural purpose. The resources available in Char Konabari are cultivable lands, grazing land and domestic animals. The total numbers of employed person of Char Konabari are 267. Out of them only 54 people engaged with on farming activities and others are involved with off farming activities. On the other hand the land area of Dakshin Borochar is about 260 hectare, out of that 130 hectare land are used for agricultural purpose, 100 hectare are non agricultural land and 30 hectare are settlement area. Cultivated land, Domestic animal, grazing land and wet land are the major natural resources of Dakshin Boro-char. The total numbers of employed people in Dakshin Boro-char are 598 and most of them are engaged in agricultural and fisheries activities. The resource map of Char Konabari and Dakshin Boro-char are shown in Figure 3 and 4 respectively.
Figure 3: Resource Map of Char Konabari

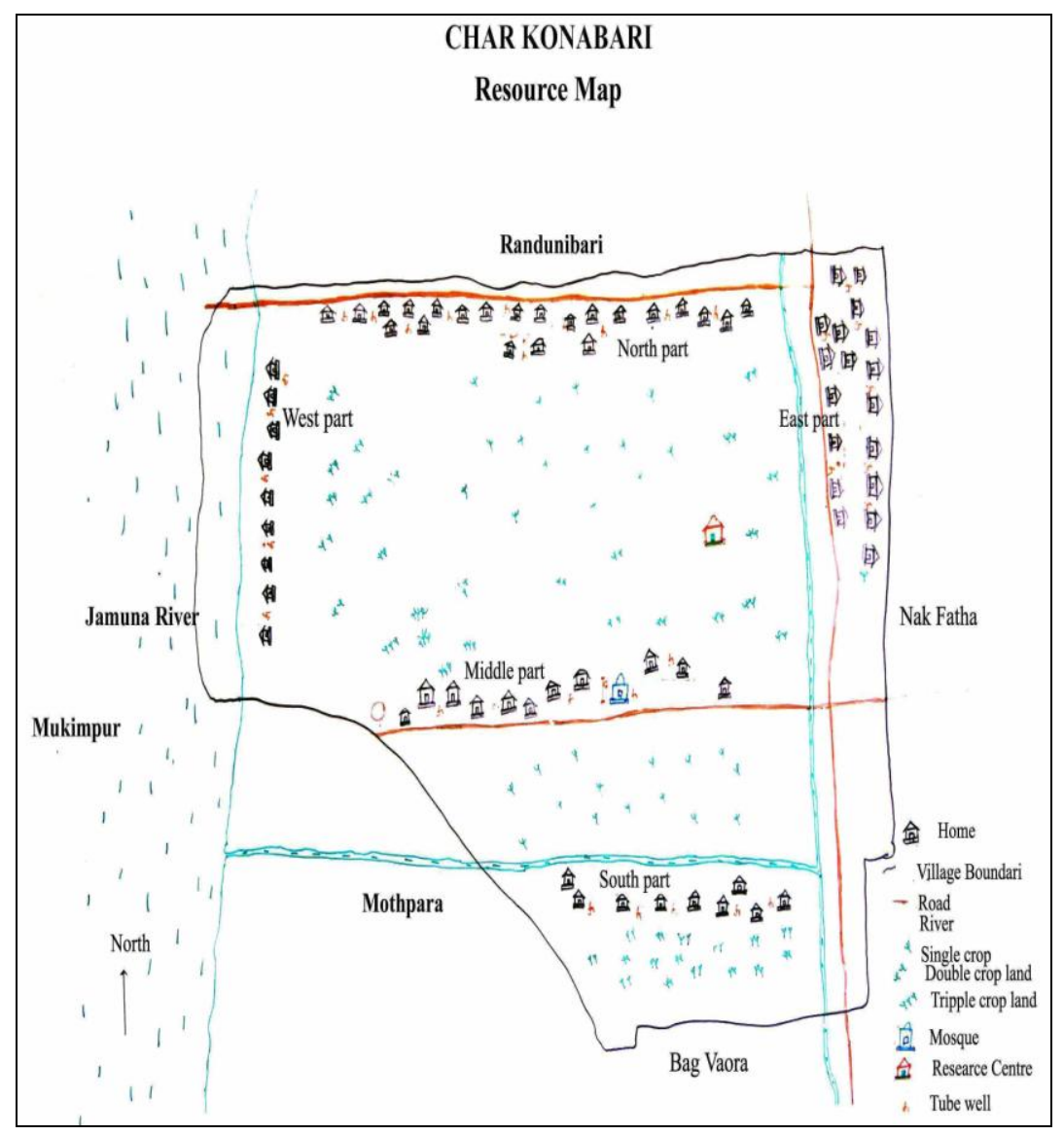


Figure 4: Resource Map of Dakshin Boro-char

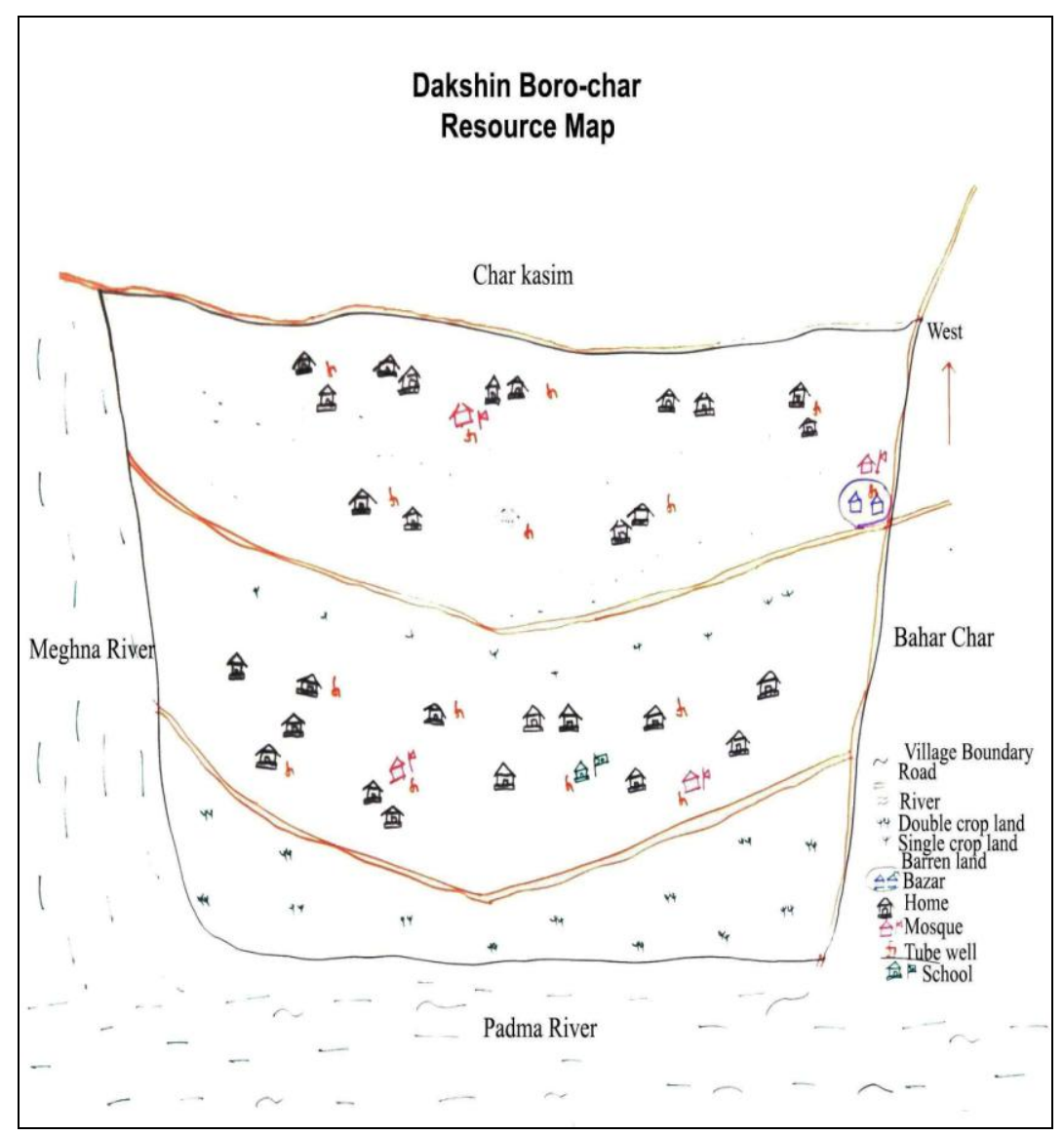

Table 4 shows that in Char Konabari one-fourth of the total employed person earned the two-third of the total yearly income of the village as well as remaining four-fifth employed person earned only one-third of the total yearly income. Table 3 also shows that in Dakshin Boro-char the majority of the yearly income comes from natural resource based occupations such as agriculture, poultry and fishing. The total yearly income of the Char Konabari and Dakshin Boro-char are about Tk.136 lac, Tk.619 lac respectively and the daily per capita income are about US\$0.54 and US\$0.87 respectively (1US\$=72Tk.). This indicates that the char dwellers economic status stands below the poverty line compare the present poverty data.

\begin{tabular}{|c|c|c|c|}
\hline Type of Activities & \multicolumn{2}{|c|}{ Livelihood Resources } & $\begin{array}{c}\text { Yearly Income } \\
\text { (Tk. in lac) }\end{array}$ \\
\hline \multicolumn{4}{|c|}{ Char Konabari } \\
\hline \multirow{5}{*}{$\begin{array}{l}\text { On Farming } \\
\text { Activities }\end{array}$} & \multicolumn{2}{|l|}{ Crops } & 29.52 \\
\hline & \multirow{2}{*}{ Livestock } & Cattle & 18.8 \\
\hline & & Goats & 4.76 \\
\hline & \multicolumn{2}{|l|}{ Poultry } & 2 \\
\hline & \multicolumn{2}{|c|}{ Livestock by product (milk \& egg) } & 36 \\
\hline $\begin{array}{l}\text { Off Farming } \\
\text { Activities }\end{array}$ & \multicolumn{2}{|c|}{ Hand loom \& others } & 45 \\
\hline \multicolumn{3}{|c|}{ Total } & 136.08 \\
\hline \multicolumn{4}{|c|}{ Dakshin Boro-char } \\
\hline \multirow{4}{*}{$\begin{array}{l}\text { On Farming } \\
\text { Activities }\end{array}$} & \multicolumn{2}{|l|}{ Crops } & 203.6 \\
\hline & \multicolumn{2}{|c|}{ Livestock (Cattle) } & 140.5 \\
\hline & \multicolumn{2}{|l|}{ Poultry } & 8.2 \\
\hline & \multicolumn{2}{|c|}{ Livestock by product (milk \& egg) } & 130.5 \\
\hline \multirow{2}{*}{$\begin{array}{l}\text { Off Farming } \\
\text { Activities }\end{array}$} & \multicolumn{2}{|l|}{ Fish } & 126 \\
\hline & \multicolumn{2}{|l|}{ Others } & 10.5 \\
\hline \multicolumn{3}{|c|}{ Total } & 619.3 \\
\hline
\end{tabular}

\section{Gender Role in Livelihood}

Women in Char Konabari are engaged in the entire process of crop production and they have knowledge in agricultural practices. Women also involved in livestock and poultry rearing. Moreover, women in this char are grown in catkin (locally known as kaisa) and during flood season catkin is the only available fodder for cattle. In Dakshin Boro-char the fodder like morning glory (It. Ipomea aquatic, locally known as kalmi lata) are available in flood season. Women are involved in collecting the fodder for cattle from the wetland. The contribution of female char dwellers in the livelihood practices does not recognized socially as well as economically.

\section{CONCLUSION}

The Ganges-Padma and the Brahmaputra-Jamuna river systems drain a huge area of land outside the territory of Bangladesh. The river systems in Bangladesh carry 2.4 billion tons of sediments (Khan, 1994), a part of which 
is deposited in the floodplains each year. As a result, every year several chars are emerged and washed out repeatedly.

The entire process of char formation would be completed within twelve to fifteen years. After fifteen years it is turn into stable char. The resources of the less stable attached char like Char Konabari is agricultural dominated but most of the char dwellers are engaged in off farm activities. The bulk amount of yearly income comes from on farming activities rather than off farming activities. However off farming activities is also popular in an attached char dwellers due to easy communication but their contribution is not remarkable in respect to on farming activities. The total yearly income of the Char Konabari is about Tk. 136 lac; where majority portion comes from on-farming activities and rest of the portion comes from offfarming activities. The daily per capita income is about US\$ 0.54 (1US\$=72Tk.). In the stable char like Dakshin Boro-char the majority of the yearly income comes from natural resource based occupations such as agriculture, poultry and fishing. The total yearly income of the Dakshin Boro-char is about Tk. 619 lac and the per capita income is about US\$ 0.87 . The present study concluded that the char dwellers' economic status stands below the poverty line compared to the present poverty data.

\section{ACKNOWLEDGEMENTS}

The authors express their gratitude to Mahmud Hasan Tuhin and Mosiur Rahman, M. Sc. student, Institute of Water and Flood Management, Bangladesh University of Engineering and Technology, for their cordial support during field survey.

\section{REFERENCES}

BARC (2005). Fertilizer Recommendation Guide. Dhaka, Bangladesh: BARC.

Chambers, R. (2002). Participatory workshops: A Source book of 21 sets of ideas and activities. London: Earthscan Publications.

EGIS. (2000). Riverine chars in Bangladesh environmental dynamics and management issues. Environment and GIS Support Project for Water Sector Planning. EGIS: University Press.

Kelly, C. and Chowdhury, M. H. K. (2002). Poverty, disasters and the environment in Bangladesh: a quantitative qualitative assessment of causal linkages. Prepared by DFTD; Government of UK, Dhaka.
Khan, M.A.H. (1994). Environmental aspects of surface water development projects in Bangladesh, In: Environment and development in Bangladesh, edited by A Atiq Rahman, Saleemul Huq, Rana Haider and Erik G Jansen, University Press: Bangladesh.

ISPAN. (1995). The dynamic physical and human environment of the reverine charlands and charland, socio economic RRA reports for the Brahmaputra-Jamuna, Meghna, Ganges and Padma rivers, and the charland flood proofing study, prepared for Flood Plan Coordination Organization (FPCO), Dhaka, Bangladesh.

Sarker, M.H., Iffat, H. and Mustafa, A. (2003). Rivers, chars and char people of Bangladesh; Intl. J. River Basin Management, IAHR, Vol. 1(1): pp. 61-80

Kothari, C.R. (1996). Research methodology, methods and techniques. New Delhi: Wishwa Prakashon. 